\title{
The impact of IT investment on firm performance based on MCDM techniques
}

\author{
Ansar Daghouri, Khalifa Mansouri, Mohammed Qbadou
}

ENSET of Mohammedia, University Hassan II of Casablanca, Morocco

\begin{tabular}{l}
\hline \hline Article Info \\
\hline Article history: \\
Received Nov 1, 2018 \\
Revised Apr 17, 2019 \\
Accepted Apr 29, 2019 \\
\hline Keywords: \\
Decision making \\
Firm performance \\
Multi-criteria \\
Non-financial performance \\
Technology investment
\end{tabular}

\begin{abstract}
In the recent past years, researchers have presented conflicting results regarding the impact of information technology investment on firm performance. Almost all studies on information technology productivity and it role for companies performance are based on data collected and metaanalysis and do not offer a methodology or prototype of analysis in any field This study presents an attempt to adopt a multi-criteria decision making approach to evaluate the non-financial performance of companies using two famous methods. Furthermore, our results try to investigate the effects of information technology investments on firms' non-financial performance. Finding show that investment in information systems is not necessarily related to achieving a good non-financial performance at the firm level.
\end{abstract}

Copyright () 2019 Institute of Advanced Engineering and Science. All rights reserved.

\section{Corresponding Author:}

Ansar Daghouri,

ENSET of Mohammedia,

University Hassan II of Casablanca,

Casablanca 20000, Morocco.

Email: dagh.ansar@gmail.com

\section{INTRODUCTION}

An investment is an asset or item acquired with the goal of generating income or appreciation; it can be with money or capital in order to gain profitable returns. Investments can be classified according to their objectives [1], replacement of equipment, increased production productivity, strategic investment, and financial investmen. Investing in information technology (IT) is a type of investment widely regarded as having enormous potential for gaining competitive advantage in the past three decades [2-5]. However, there has a debate of IT investment effects on firm's performance. The majority of researchers confirm that IT investment has a positive impact on firm performance [6,7], the most of studies are based on data collected and relates to financial performance. The main objective of this manuscript is to develop a multi-criteria decision support approach in order to build a hierarchical model to evaluate the non-financial performance at the firm level and then to analyze the contribution of the investment in the IT to the realization of this performance.

This study focuses on two axes: it validates the interest of multi-criteria decision making (MCDM) in a context that is not traditionally theirs, namely the evaluation of the performance using a combination of two famous and the most used MCDM methods: AHP and TOPSIS, also it investigates the impact of IT investment on the non-financial performance of companies operating in three sectors selected for this study. The structure of this paper is as follows: section 2 offers a literature review of previous studies about non-financial performance and IT investment to demonstrate the purpose of this paper. In the section of methods, the two used MCDM methods are explained. Next section, presents the results of work methodology with discussions of findings. Then, the concluding remarks are presented. 


\section{LITERATURE REVIEW}

\subsection{Non-financial performance}

Based on the state of the art, performance is defined as the combination of effectiveness and efficiency [8] it can't be defined as a simple notion; it is a concept that encompasses several dimensions. Generally, we can subdivide to financial and non-financial performance. In our case, we are interested to non-financial performance. Non-financial performance can tell managers about what is going to happen with the financial results in the future years [9]. This type of performance includes any quantitative measures of individual or entity's performance that is not expressed in monetary units [10]. Performance measurement [11] is hard because it describes and implements the strategy that is not directly observable, the monitoring of organization and the improving coordination, which are influenced by uncontrollable events.

In this section, we will present an overview of previous studies related to non-financial measures:

- By reviewing previous studies related to non-financial performance, we have found different indicators such as [12-14]: product quality, customer satisfaction, on time delivery, innovation measures, attainment of strategic objectives, market share, efficiency, productivity, employee satisfaction.

- The most non-financial indicators used and cited are [15-17], customer satisfaction, market share, employee feedback, human resources, and product quality.

- The Balanced Scorecard developed by Kaplan and Norton [18] provides financial and non-financial measurements and focused on customer's point of view.

- Abdel-Maksoud [19] proposed a model involving five non-financial performance indicators: customer satisfaction, product quality, and on-time delivery, efficiency and utilization and employee morale.

- Philips and Louvieris [20] introduced three major success factors: quality of service, customer relationship management and customer profiling.

- All these studies confirmed that non-financial performance is very important when evaluation firm's performance even in the financial sector [21-23].

\subsection{IT investment and firm performance}

The relation between IT investment and firm performance has been investigated since 1980 [24-27]. The majority of results studies confirm the IT investment's impact on firm performance. Many theoretical paradigms in evaluating the IT's contribution to firm performance have cited in literature: theoretical model of IT resources [28], general purpose technology theory [29], the neoclassical theory [30, 31], the resourcebased theory [32] and the productivity paradox theory [24]. The findings of all studies can be grouping to three possibilities: studies confirming the positive effects of IT investment on firm performance [2, 3, 5, 33-36], studies confirming the IT paradox [37-39] and studies (minority) have found no impact of IT investment on firm performance [40-41].

\section{MCDM METHODS}

There are a number of MCDM methods multiple criteria [42-44] that can be used to facilitate decision-making process. In this work we used a combined approach of two most popular methods namely AHP and TOPSIS methods.

\subsection{AHP method}

The AHP procedure requires the following steps [45-47]:

- Construct the matrix Uij of order $m$ if the compared entities are criteria, or of order $n$ if the compared entities are alternatives

- Construct the comparison matrices whose values are obtained by transforming the judgments into numerical values according to the Saaty scale (Scale of Binary Comparisons), respecting the principle of reciprocity

$$
\left\{\begin{array}{c}
\sum_{j=1}^{n} U_{i j} W_{j}=\lambda_{\max } W_{i} \text { pour } i=1 \cdots n \\
\sum_{i=1}^{n} W_{i}
\end{array}\right.
$$

\subsection{TOPSIS method}

The TOPSIS procedure consists of the following steps [48-51]:

- Normalize performance:

$$
e_{i j}^{\prime}=\frac{g_{j}\left(a_{i}\right)}{\sqrt{\left(g_{j}\left(a_{i}\right)^{2}\right)}}
$$

Where: $\mathrm{i}=1 \ldots \mathrm{m}$ and $\mathrm{j}=1 \ldots \mathrm{n}$ 
- Calculate the product of normalized performance:

$$
\begin{aligned}
& e_{i j}^{\prime \prime}=\pi_{j} * e_{i j}^{\prime} \\
& \sum_{j=1}^{n} \pi_{j}=1
\end{aligned}
$$

Where: $i=1 \ldots m$ and $j=1 \ldots n$

- Determine the positive and the negative ideal solutions:

$$
\begin{gathered}
a^{*}=\left\{\max _{i} e_{i j}^{\prime \prime}, i=1 \cdots m \text { et } j=1 \cdots n\right\} ; a^{*}=\left\{e_{j}^{*}, j=1 \cdots n\right\}=\left\{e_{1}^{*}, e_{2}^{*} \cdots e_{n}^{*}\right\} ;(4) e_{j}^{*}=\max \left\{e_{i j}^{\prime \prime}\right\} \\
a^{-}=\left\{\min _{i} e_{i j}^{\prime \prime}, i=1 \cdots m \text { et } j=1 \cdots n\right\} ; a^{*}=\left\{e_{j}^{-}, j=1 \cdots n\right\}=\left\{e_{1}^{-}, e_{2}^{-} \cdots e_{n}^{-}\right\} ; \\
e_{j}^{-}=\min \left\{e_{i j}^{\prime \prime}\right\}
\end{gathered}
$$

- Calculate the separation measures:

$$
D_{i}^{*}=\sqrt{\sum_{j=1}^{n}\left(e_{i j}^{\prime \prime}-e_{j}^{*}\right)^{2}} \forall: i=1 \cdots m ; \quad D_{i}^{-}=\sqrt{\sum_{j=1}^{n}\left(e_{i j}^{\prime \prime}-e_{j}^{-}\right)^{2}} \forall: i=1 \cdots m ;
$$

- Calculate the relative closeness coefficient to the ideal solution:

$$
C C_{i}^{*}=\frac{D_{i}^{*}}{D_{i}^{*}+D_{i}^{*}} \forall: i=1 \cdots \text { m et } 0 \leq C C_{i}^{*} \leq 1
$$

- $\quad$ Rank the alternatives.

\section{IMPLEMENTATION}

\subsection{Purpose of study}

The study focuses mainly on the contribution of IT investments in achieving the firm's non-financial performance. The purpose is to provide a new methodology to evaluate the non-financial performance of firms using two MCDM methods namely AHP and TOPSIS. The first method was used to calculate the weights of each criterion in evaluating non-financial performance, subsequently; the firms were evaluating using the TOPSIS method. Furthermore, this work analyzes the relationship between IT investment and non-financial performance at firm level. We examine also the interaction between a set of non-financial indicators and the degree of IT investment.

The paper implements the research methodology in three sectors, namely: financial sector, construction industry sector and service companies, chosen based on their variation in the use of information technologies. The majority of previous studies have dealt with the financial performance of firms [52-54], in order to overcome this deficiency, this study aim to introduce a new technique for evaluating and analyzing the non-financial firm's performance using multi-criteria decision making methods and its relation with IT investment.

\subsection{Work methodology}

The work methodology as shown in Figure 1, consists of four main steps as summarized in the following figure: step 1: review previous studies relating to non-financial performance, information technology investment and their contribution;step 2: choose the sectors in which we will apply our approach, we selected 3 sectors;step 3: identify the evaluation criteria and sub-criteria considered as the most important non-financial performance measures;step 4: apply AHP method;step 5: apply TOPSIS method;step 6: achieve the final ranking results of studies firms;step 7: define investment values of each alternative and step 8-9: analyze the contribution of IT investments in the achievement of non-financial performance of firms belonging on studies sectors. The description of each step will be given in the following sections. 


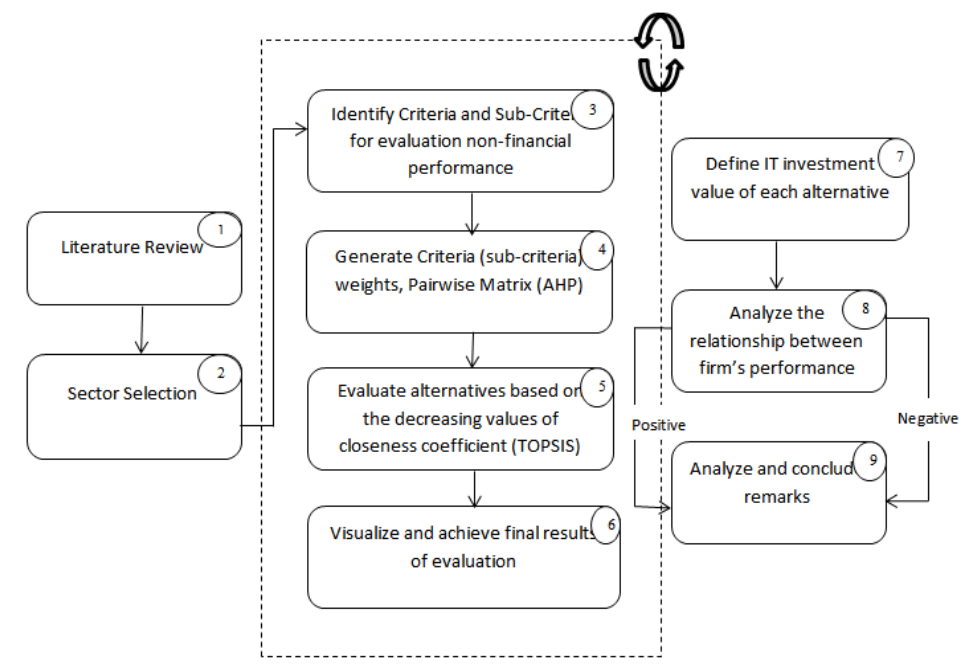

Figure 1. Work methodology

\subsection{Implementation}

To validate our work methodology, we choose to work on firms operating in three sectors selected for the reasons mentioned previously. Therefore, our first objective was the choice of criteria and sub-criteria that will be used during this research. The evaluation criteria were taken from previous studies and researchers related to non-financial performance evaluation $[55,56]$. The hierarchical model contains 6 criteria and 19 sub-criteria as shown in Table 1.

Table 1. Hierarchical representation of criteria

\begin{tabular}{ll}
\hline Main Criteria & Sub Criteria \\
\hline Customer $\left(\mathrm{C}_{1}\right)$ & CustomerNumber $\left(\mathrm{C}_{11}\right)$, CustomerSatisfaction $\left(\mathrm{C}_{12}\right)$ \\
& and ComplaintsNumber $\left(\mathrm{C}_{13}\right)$ \\
Expansion and Market Share $\left(\mathrm{C}_{2}\right)$ & $\begin{array}{l}\text { BrancheNumber }\left(\mathrm{C}_{21}\right), \text { NewProductsNumber }\left(\mathrm{C}_{22}\right) \text { and } \\
\text { NewService }\left(\mathrm{C}_{23}\right)\end{array}$ \\
Employees $\left(\mathrm{C}_{3}\right)$ & Headcount $\left(\mathrm{C}_{31}\right)$, AverageAge $\left(\mathrm{C}_{32}\right)$, Satisfaction $\left(\mathrm{C}_{33}\right)$ \\
& and TrainingInvestment $\left(\mathrm{C}_{34}\right)$ \\
Service Quality $\left(\mathrm{C}_{4}\right)$ & OnTimeDelivery $\left(\mathrm{C}_{41}\right)$, CommunicationCapability $\left(\mathrm{C}_{42}\right)$, \\
& RateDelay $\left(\mathrm{C}_{43}\right)$, Availability $\left(\mathrm{C}_{44}\right)$ and Access $\left(\mathrm{C}_{45}\right)$ \\
Environment $\left(\mathrm{C}_{5}\right)$ & TotalPaperConsumption $\left(\mathrm{C}_{51}\right)$ and EnergyUse $\left(\mathrm{C}_{52}\right)$ \\
Security $\left(\mathrm{C}_{6}\right)$ & RiskRate $\left(\mathrm{C}_{61}\right)$ and Breakdown $\left(\mathrm{C}_{63}\right)$ \\
\hline
\end{tabular}

Data collection was conducted among fifty firms in each sector and the weights of criteria and sub-criteria were calculated using AHP method. Thereafter, TOPSIS method was applied and based on the decreasing values of closeness coefficient alternatives are ranked from most valuable to worst. The second part concerns the study of the relationship between IT investment and firm's non-financial performance. This work enrichies the debate on the performance evaluation by adopting a multi-criteria approach to evaluate non-financial performance of firms and to study its relation with IT investment. There are two cases to distinguish; the presence of a positive or negative impact. Furthermore, this work indirectly controls two main factors that can influence the contribution of IT investment in the achievement of non-financial performance at the firm level which are the size of firm and its sector. This observation is confirmed by the results of the study.

\subsection{Proposed framework}

To implement our work methodology, we propose a prototype of framework that consists of 3 parts as shown in Figure 2. 


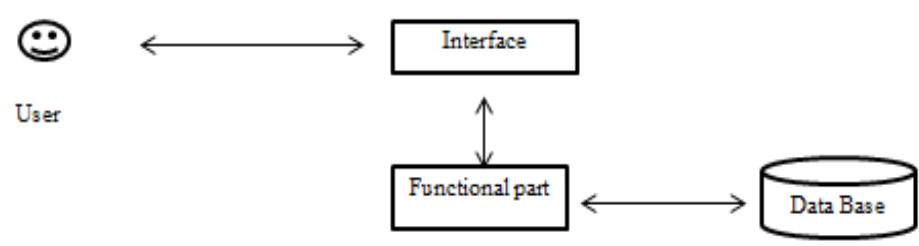

Figure 2. Proposed framework's architecture

Interface: after authentication, the framework user can start the use of application and enter the evaluation data with the possibility to modify criteria and sub-criteria;

- Data Base: its role is to store the various data that will be used in the next steps of evaluation or that will serves as archives to make comparisons. We chose to work with SQL Lite as the size of data is reduced;

- Functional Part: its purpose is to execute the steps of our work methodology based on the implementation of AHP and TOPSIS methods known by the complexity of their calculations. The proposed system begin when the user choose the sector that will be evaluated. The first main step on this part is the implementation of AHP method, through the several interfaces which use combo boxes to input values, the others interfaces lead to calculate the weights of criteria (main criteria and sub-criteria). The second step aims to implement the TOPSIS method based on the data input in by framework's user. The final step consists on the analyses of relationship between IT investment and firm's non-financial performance. A prototype was developed in Java programming language; we could not include all the interfaces in the article to not exceed the number of pages indicated, we presente some interfaces as shown in Figure 3.

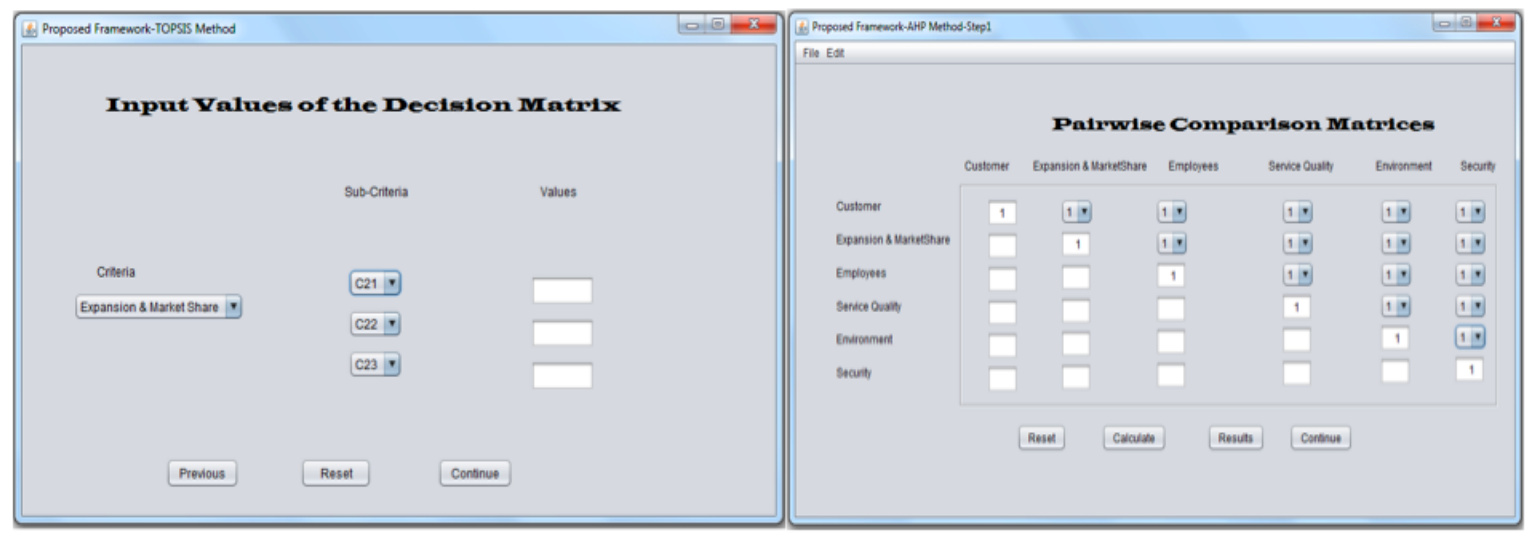

Figure 3. Prototype interfaces

\section{ANALYSIS RESULTS}

\subsection{AHP method analysis}

The prototype of resulting system start by asking users to determine the level of importance of chosen criteria (sub-criteria) compared to others. Based on the data, the calculation method of AHP can begin to obtain the weight of each criterion and sub-criterion. The hierarchical structure for evaluating the non-financial performance as shown in Figure 4 .It should be noted that the values of this study were obtained by calculating the average values given by the experts responsible in each of the three sectors. 


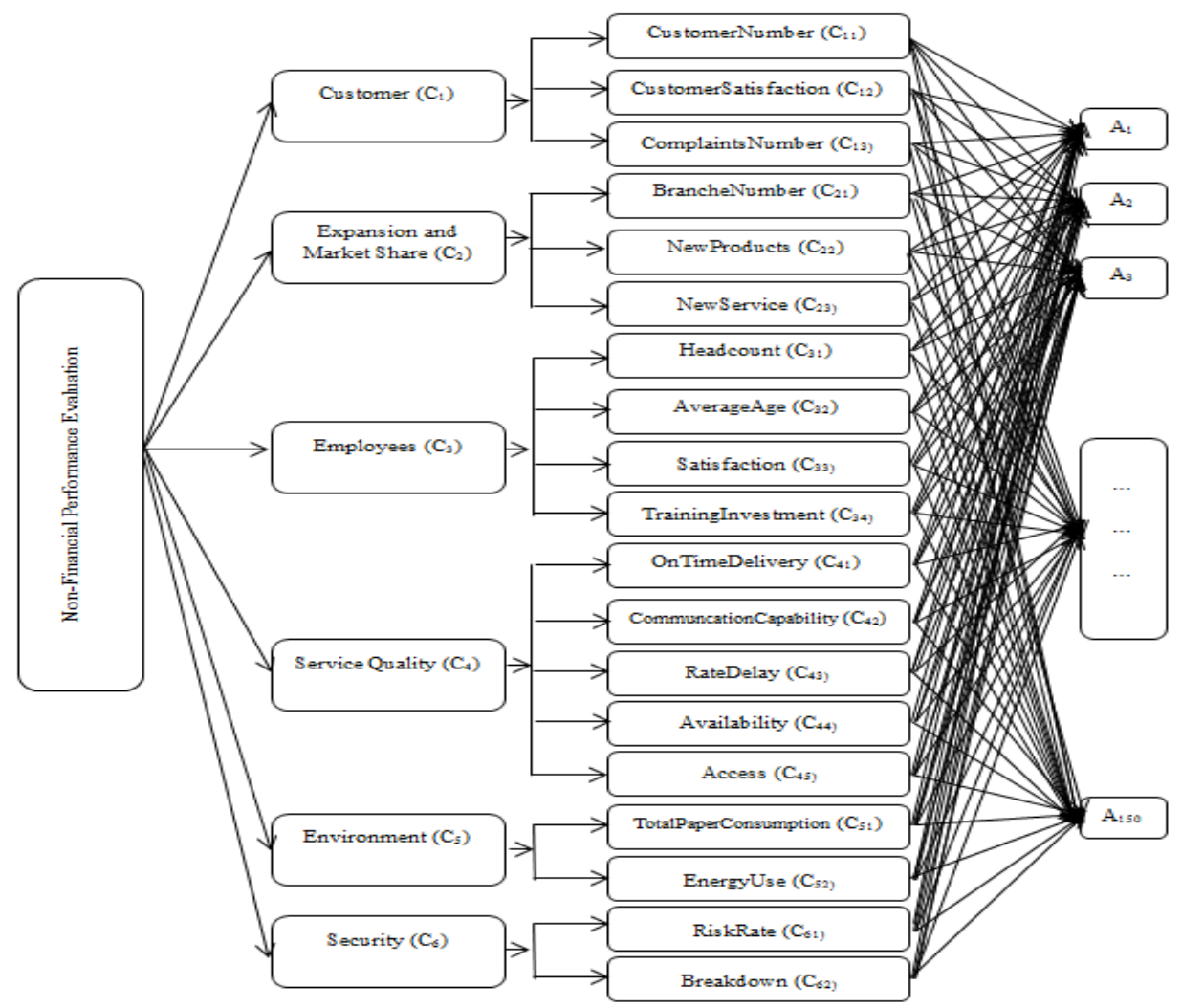

Figure 4. Hierarchical structure for the non-financial performance evaluation

Starting by the financial sector and implementing the AHP equations (1), through the proposed prototype interfaces, the normalized weight vector of main criteria is: $\mathrm{W}=(0.36 ; 0.20 ; 0.17 ; 0.16 ; 0.07 ; 0.03)$ as shown in Figure 5, the most valuable criterion with the weight of 0.36 is "Customer".

Banks Weight Criteria

Figure 5. Sector's weight criteria

In the construction industry sector, the priority vector of criteria weights is: $\mathrm{W}=(0.32 ; 0.19 ; 0.17$; $0.16 ; 0.11 ; 0.04)$ as shown in Figure 5 , the highest weight is 0.32 which corresponds to the first criterion presenting customer. Concerning the third sector, the main criteria weight is: $\mathrm{W}=(0.43 ; 0.20 ; 0.17 ; 0.12$; $0.04 ; 0.02$ ) as shown in Figure 5 , the first criterion still having the greatest value.

From these results, we can conclude that for the evaluation of non-financial performance of firms, the most dominant criterion is the customer regardless of the sector or the size of the company. It is a logical result given the importance of the customers who are the mark of a service quality and a good image of the firm, and then we have the other criteria. Still analyzing the results of AHP method implementation, we notice an increase in weight for the last two criteria namely environment and security in the construction industry sector that have passed from 0.04 to 0.11 and 0.02 to 0.04 which is normal given the particularities of this sector being a risk factor and its impact on the environment. 


\subsection{TOPSIS method analysis}

From the pairwise comparison, the normalized weight of criteria and sub-criteria are obtained. Then, we have process to the TOPSIS method implementation, the process is begun data values based on each alternative. Given the large number of alternatives, we chose to display just one example as shown in Table 2. To facilitate the task of data entry by evaluators, we chose to work with intervals of values to make the evaluation.

Table 2. Scoring alternative 1

\begin{tabular}{llllll}
\hline Criteria & Sub-Criteria & Values & Criteria & Sub-Criteria & Values \\
\hline $\mathrm{C}_{1}$ & $\mathrm{C}_{11}$ & $\mathrm{~A}$ & $\mathrm{C}_{2}$ & $\mathrm{C}_{21}$ & $\mathrm{C}$ \\
& $\mathrm{C}_{12}$ & $\mathrm{AC}$ & & $\mathrm{C}_{22}$ & $\mathrm{AA}$ \\
& $\mathrm{C}_{13}$ & $\mathrm{~F}$ & & $\mathrm{C}_{23}$ & $\mathrm{E}$ \\
$\mathrm{C}_{3}$ & $\mathrm{C}_{31}$ & $\mathrm{~A}$ & $\mathrm{C}_{4}$ & $\mathrm{C}_{41}$ & $\mathrm{~A}$ \\
& $\mathrm{C}_{32}$ & $\mathrm{AA}$ & & $\mathrm{C}_{42}$ & $\mathrm{AC}$ \\
& $\mathrm{C}_{33}$ & $\mathrm{~F}$ & & $\mathrm{C}_{43}$ & $\mathrm{D}$ \\
& $\mathrm{C}_{34}$ & $\mathrm{G}$ & & $\mathrm{C}_{44}$ & $\mathrm{I}$ \\
& & & & $\mathrm{C}_{45}$ & $\mathrm{~L}$ \\
$\mathrm{C}_{5}$ & $\mathrm{C}_{51}$ & $\mathrm{~B}$ & $\mathrm{C}_{6}$ & $\mathrm{C}_{61}$ & $\mathrm{EA}$ \\
& $\mathrm{C}_{52}$ & $\mathrm{AA}$ & & $\mathrm{C}_{62}$ & $\mathrm{HB}$ \\
\hline
\end{tabular}

From the data of this alternative, we perform the conversion to form such a decision matrix as shown in Table 3. To rank the different alternatives, we implement in order the (2)-(8). We continue the process of calculating the distance between the values of each alternative against the positive ideal solution and the negative ideal solution. Further, the ranking of alternatives of the study is obtained.

Table 3. Decision matrix (alternative1)

\begin{tabular}{llllll}
\hline Criteria & Sub-Criteria & Values & Criteria & Sub-Criteria & Values \\
\hline $\mathrm{C}_{1}$ & $\mathrm{C}_{11}$ & 1 & $\mathrm{C}_{2}$ & $\mathrm{C}_{21}$ & 3 \\
& $\mathrm{C}_{12}$ & 3 & & $\mathrm{C}_{22}$ & 1 \\
& $\mathrm{C}_{13}$ & 3 & & $\mathrm{C}_{23}$ & 2 \\
$\mathrm{C}_{3}$ & $\mathrm{C}_{31}$ & 1 & $\mathrm{C}_{4}$ & $\mathrm{C}_{41}$ & 1 \\
& $\mathrm{C}_{32}$ & 1 & & $\mathrm{C}_{42}$ & 3 \\
& $\mathrm{C}_{33}$ & 3 & & $\mathrm{C}_{43}$ & 1 \\
& $\mathrm{C}_{34}$ & 1 & & $\mathrm{C}_{44}$ & 3 \\
& & & & $\mathrm{C}_{45}$ & 3 \\
$\mathrm{C}_{5}$ & $\mathrm{C}_{51}$ & 2 & $\mathrm{C}_{6}$ & $\mathrm{C}_{61}$ & 2 \\
& $\mathrm{C}_{52}$ & 1 & & $\mathrm{C}_{62}$ & 1 \\
\hline
\end{tabular}

\subsection{IS investment and firm performance}

This study is based on data of fifty firms belonging to the three studied sectors, each with a different information technology consumption rate. We first propose a hierarchical model to evaluate the non-financial performance of these firms using MCDM methods. Since the majority of research studying the correlation between information system investment and financial performance worked with financial performance, we chose to treat non-financial performance. Subsequently, we studied the correlation between the two variables; the results from previous researches are mixed. In general way, firms invest on IT to achieve better competitive advantages through reducing costs, but the IT budget is varied from one sector to another. Given the number of firms in each sector, ten companies from each sector were selected based on the results of the non-financial performance evaluation (the first three, the four averages and the last three).

The financial sector is considered as the biggest investor in the IT. The Figure 6 shows the results of the IT investment percentage compared to the firm's turnover. It can be concluded that more than $80 \%$ of financial firms invest between 21 and $60 \%$ of their turnover in information systems; which is a huge investment given the large turnover of banks. The curve shows the ranking of the firm's non-financial performance according to the IT investment as shown in Figure 6, we find that the impact of IS investment does not always ensure the performance of the company, as shown concretely the example of the B3 bank which is ranked third performance rating but in return invests only a percentage between $1-20 \%$. Unlike the B9 bank which invests $61-80 \%$ of its turnover but is ranked among the last three firms in terms of performance. These two contradictory examples lead us to believe that there are other factors that influence the contribution of IT investment in achieving the non-financial performance. 

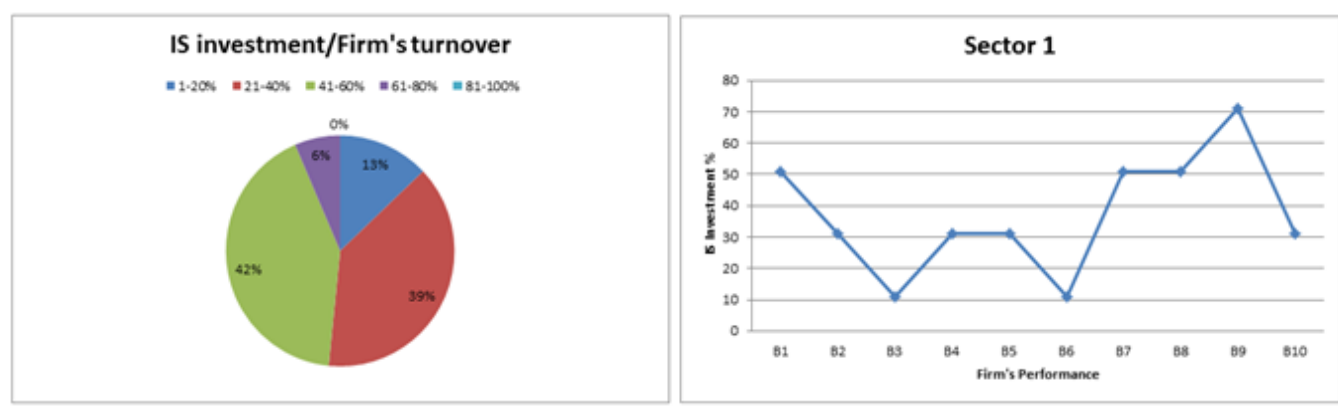

Figure 6. Financial sector results

Concerning the construction industry sector, as shown in Figure 7, only $6 \%$ of the firms in the construction industry invest between 21 and $40 \%$ of their turnover in information system and almost all firms contribute between 1 and $21 \%$ of their turnover in the investment, a result that proves more than this sector uses almost no computer and even more does not believe that with the use of information system it can improve the performance of its companies.
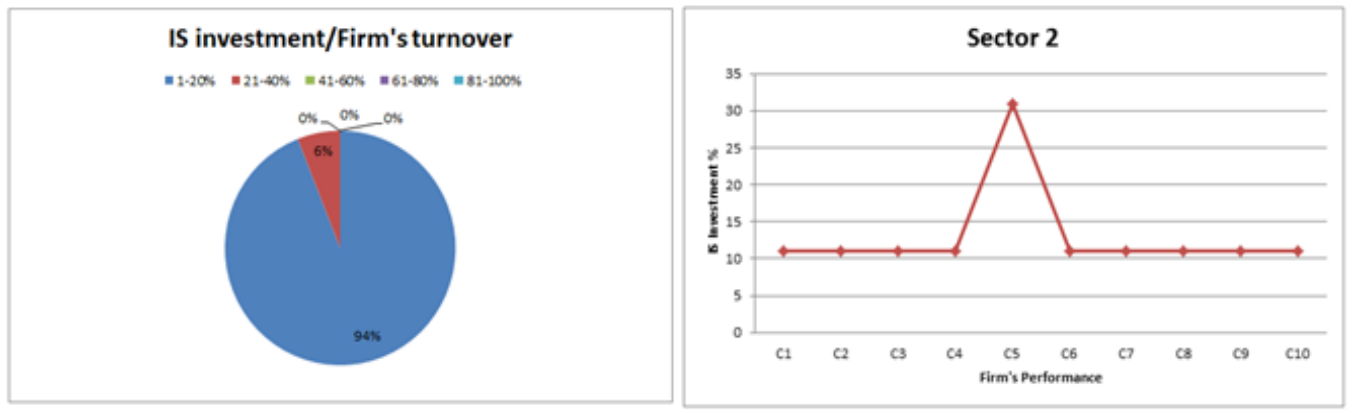

Figure 7. Construction industry sector results

For the results of the study of the impact of IS investment on performance, we find the same remark as the first sector; IS investment is not always a factor in the firm's non-financial performance, $\mathrm{C} 1 \mathrm{ranked}$ first performance only invests 1-20\% of its turnover yet C5 is among the minority of companies that invest between $21-40 \%$ but it is not ranked among the first.

The last sector is the one that ensures the balance between the two previous ones, it invests moderately in information systems and this is clear from the results shown in Figure 8, even if we notice an increase of number in the first tranche which concerns 1-20\% IT investment; this can be explained by the fact that in this same sector, there are companies that believe more than the value created by the IT but hesitated in terms of investment.
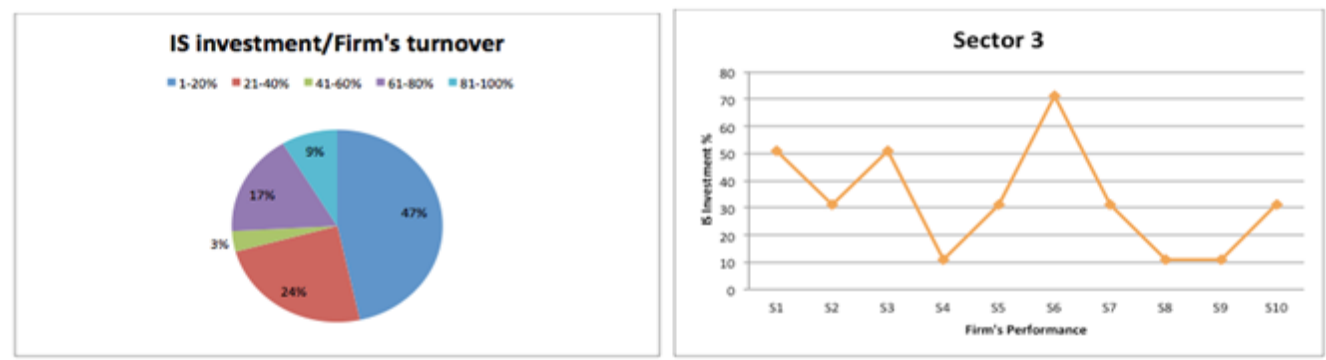

Figure 8. Service companies sector results 
The contribution of IT investment in the achievement of non-financial performance of service companies is one of the objectives of this study, in the Figure 7, we always come back to the remark we made since the beginning of the analysis of this correlation and it is that the investment in IS does not always ensure the performance of the companies, we notice the company S6 which invests between $61-80 \%$ of its turnover but still not ranked the first; it confirms more that a successful company is not necessarily the one that invests the most in information systems.

\section{CONCLUSION AND PERSPECTIVES}

This study uses data from 150 companies operating in three sectors to determine the contribution of IT investment in the achievement of non-financial firm's performance. This paper proposes a framework based on MCDM methods to analyze firm's performance; criteria and sub-criteria were chosen from previous researches. Based on the results obtained, we can conclude that the weight's criteria and sub-criteria change from one sector to another. For example, weight's criteria of environment and security increases when we have passed from financial sector or service companies to construction industry, so it is unfair to establish a generic model to evaluate the non-financial firm's performance belonging in different sectors.

This paper also investigates the correlation between IT investment and non-financial firm's performance. This relation is qualified as a very complicated issue, it can be influenced by many factors: sector's type, firm's size, employee's skills and firm's organizational culture. Coming back to the first sector chosen, it is the most consumer computer sector, that is clear from IT investment percentage; more than $80 \%$ of financial firms invest between 21 and $60 \%$ of their turnover in information systems, which is a huge investment, unfortunately, this not ensure a good performance; we have financial firm's who invest heavily on IS but there are ranked at last among the others on term of non-financial performance, so the IS investment don't ensure a good performance, the same remark is valid for the others two sectors. What varies is the IT investment values; for the construction industry sector, 94\% of firms invest just between 1 and $20 \%$ of their turnover on IT investment which is mediocre given the firm's size and their turnover. Service companies invest moderately on information systems. To summarize, the results of this study show that investment in information technologies is not necessarily related to superior non-financial performance, on the other hand, IT investment depend on the size and the type of the firms.

The work done in this article has yielded interesting results. In fact, the approach developed for the construction of a performance evaluation model has shown the interest of a hierarchical model for modeling a vague concept such as performance and thus to study the contribution of IT investments.For the future work, we will work on a larger sample to verify the accuracy of our results and even on other sectors while identifying a propietary valuation model for each one.

\section{REFERENCES}

[1] B. Huijie, "A Study on Leverage and Firm Investment: Chinese Evidence," Program Economics of Innovation and Growth Royal Institute of Technology (KTH), 2010.

[2] J. Sangjoon, "The nexus between IT investment and banking performance in Korea," Global Econ Review, vol. 35, no. 1, pp. 67-96, 2006.

[3] S. O. Kwon, "Impact of IT investment on firm performance: Focusing on four moderators," Master's thesis, Korea advanced Institute of Science and Technology, 2007.

[4] J. K. Kim, J. Y. Xiang, and S. Lee, "The impact of IT inevtment on firm performance in China: An empirical investigation of the Chinese electronics industry," Technological Forecasting and Social Change, vol. 76, no. 5, pp. 678-687, 2009.

[5] L. Kleis, P. Chwelos, R. V. Ramirez and I. Cockburn, "Information technology and intagible output: The impact of IT investment on innovation productivity," Information Systems Research, vol. 23, no. 1, pp. 42-59, 2012.

[6] E. Brynjolfsson and L. M. Hitt, "Paradox lost? Firm-level evidence on the returns to information systems spendig," Management Science, vol. 42, no. 2, pp. 541-558, 1996.

[7] J. Dedrick, V. Gurbaxani and K. L. Kraemer, "Information technology and economic performance: a critical review oh the empirical evidence," ACM Computing Surveys, vol. 35, no. 1, pp. 1-28, 2003.

[8] H. A. Bassioni, A. F. Price and T. M. Hassan, "Performance Measurement in Construction Firms," Journal of Management in Engineering, vol. 20, no. 2, pp. 42-50, 2004.

[9] M. Kennerly and A. Neely, "A framework of the factors affecting the evolution of performance measurement systems," International Journal of Operations \& Production Management, vol. 22, no. 11, pp. 1222-1245, 2002.

[10] J. Bogićević, V. Domanović and B. Krstić, "The Role Of Financial And Non-Financial Performance Indicators In Enterprise Sustainability Evaluation," ЕКОНОМИКА, vol. 62, no. 3, pp. 1-13, 2016.

[11] M. A. Malina and F. H. Selto, "Choice and change of measures in performance measurement models," Management Accounting Research, vol. 15, pp. 441-469, 2004. 
[12] S. Datar, S. C. Kulp and R. A. Lambert, "Balancing Performance Measures," Journal of Accounting Research, vol. 39, no. 1, pp. 75-92, 2001.

[13] S. Ibrahim and C. Lloyd, "The association between non-financial performance measures in executive compensation contracts and earnings management," Journal of Accounting and Public Policy, vol. 30, pp. 256-274, 2011.

[14] C. D. Ittner, D. F. Larcker and M. W. Meyer, "Subjectivity and the Weighting of Performance Measures: Evidence from a Balanced Scorecard," The Accounting Review, vol. 78, no. 3, pp. 725-758, 2003.

[15] R. S. Kaplan and D. P. Norton, "The Balanced Scorecard- Measures that Drive Performance," Harvard Business Review, pp. 70-79, 1992.

[16] H. Reijonen and R. Komppula , "Perception of success and its effect on small firm performance," Journal of Small Business and Enterprise Development, vol. 14, no. 4, pp. 689-701, 2007.

[17] S. Milan and R. Aluç, "Performance success factors of non-financial performance measurement, a literature review," Bachelor Thesis Accounting, auditing and control, July 2017.

[18] R. Kaplan and D. Norton, "Using the balanced scorecard as a strategic management system," Harvard Business Review, pp. 75-85, 1996.

[19] A. Abdel-Maksoud, D. Dugdale and R. Luther, "Non-financial performance measurement in manufacturing companies," The British Accounting Review, vol. 37, pp. 261-297, 2005.

[20] P. Philips, P. Louvieris, "Performance Measurement Systems in Tourism, Hospitality, and Leisure Small MediumSized Enterprises: A Balanced Scorecard Perspective," Journal of Travel Research, vol. 44, pp. 201-211, 2005.

[21] T. Zhelyuk and C. L. Popa, "Non-financial measurements in banking industries of Sweden, Romania and Ukraine," Master Thesis, The Department of Business Administration Lund University, 2009.

[22] P. V. Gijsel, "The importance of non-financial performance measures during the economic crisis," Master Thesis, Tilburg University: School of Economics and Management, 2012.

[23] C. Strandberg, "Non-financial metrics in the financial sector," in National Credit Union Social Responsibility Forum, 2014.

[24] R. Solow, "We'd better watch out," New York Times Book Review, Jul 1987.

[25] J. Barney, "Firm Resources and Sustained Competitive Advantage," Journal of Management, vol. 17, no. 1, pp. 99-120, 1991.

[26] E. Brynjolfsson and L. M. Hitt, "Beyond Computation: Information Technology, Organizational Transformation and Business Performance," Journal of Economic Perspectives, vol. 14, no. 4, pp. 23-48, 2000.

[27] J. Dedrick, V. Gurbaxani and L. K. Kraemer, "Information Technology and Economic Performance: a Critical Review of the Empirical Evidence," ACM Computing. Survey, vol. 35, no. 1, pp. 1-28, 2003.

[28] S. Aral and P. Weill, "IT Assets, Organizational Capabilities, and Firm Performance: How Resource Allocations and Organizational Differences Explain Performance Variation," Journal of Organizational Science, vol. 18, no. 5, pp. 763-780, 2007.

[29] P. Guerrieri and P. C. Padoan, "Modelling ICT as a General Purpose Technology," Collegium, Special Edition, European Commission and College of Europe, no. 35, 2007.

[30] K. J. Stiroh, "Computers, Productivity, and Input Substitution," Economic Inquiry, vol. 36, no. 2, pp. 175-191, 1998.

[31] A. M. Jamali, H. Voghouei, N. G. Nor, "The Role of Information Technology on the Growth of Firms: A Value Added Consideration," Journal of Theoretical and Applied Information Technology, vol. 57, no. 3, pp. 313-325, 2013.

[32] T. Liang, J. You and C. Liu, "Resource-based perspective on information technology and firm performance: A meta analysis," Industrial Management \& Data Systems, vol. 110, no. 8, pp. 1138-1158, 2010.

[33] R. Indjikian and D. S. Siegel, "The impact of investment in IT on economic performance: Implications for developing countries," World Dev, vol. 33, no. 5, pp. 681-700, 2005.

[34] M. Campbell, "What a difference a year makes: Time lag effect of information technology investment on firm performance," Comput Elect Commun, vol. 22, no. 3, pp. 237-255, 2012.

[35] E. Berghout and C.-W. Tan, "Understanding the impact of business cases on IT investment decisions: An analysis of municipal e-government projects," Inf Manag, vol. 50, pp. 489-506, 2013.

[36] A. Saunders and E. Brynjolfsson, "Valuing information technology related intangible assets," MIS Q, vol. 40, no. 1, pp. 83-110, 2016.

[37] M. C. Anderson, R. D. Banker and S. Ravindran, "The new productivity paradox," Commun ACM, vol. 46, pp. 91-94, 2003.

[38] S-M. Huang, C-S. Ou, C-M. Chen and B. Lin, "An empirical study of relationship between IT investment and firm performance: A resource-based perspective," Eur J Oper Res, vol. 173, pp. 984-999, 2006.

[39] S. Otim, K. E. Dow, V. Grover, J. A. Wong, "The impact of information technology investments on downside risk of the firm: Alternative measurement of the business value of IT," J Manag Inf Sys, vol. 29, no. 1, pp. 195-193, 2012.

[40] J. Ho, A. Wu and S. X. Xu, "Corporate governance and returns on information technology investment: Evidence from an emerging market," Strat Manag J, vol. 32, no. 6, pp. 595-623, 2011.

[41] L. Motiwalla, M. R. Khan and S. Xu, "An intra- and inter-industry analysis of e-business effectiveness," Inf Manag, vol. 2, pp. 651-667, 2005.

[42] E. K. Zavadskas, Z. Turskis and S. Kildiene, "State of art surveys of overviews on MCDM/MADM methods," Technol. Econ. Dev. Econ, pp. 165-179, 2014.

[43] M. Velasquez and P. T. Hester, "An Analysis of Multi-Criteria Decision Making Methods," International Journal of Operations Research, vol. 10, no. 2, pp. 56-66, May 2013. 
[44] A. Singh and S. K. Malik, "Major MCDM Techniques and their application-A Review," IOSR Journal of Engineering, vol. 4, no. 5, pp. 15-25, May 2014.

[45] T. L. Saaty, "How to Make a Decision: The Analytic Hierarchy Process," European Journal of Operational Research, pp. 9-26, 1970.

[46] T. L. Saaty, Decision Making for Leaders: The Analytic Hierarchy Process for Decisions in a Complex World, Third Revised Edition ed.: RWS Publications, 2012.

[47] E. Mu and M. Pereyra-Rojas, "Practical Decision Making An Introduction to the Analytical Hierarchy Process (AHP) Using Super Decisions V2," Springer, 2017.

[48] C. L. Hwang and K. Yoon, "Multiple attributes decision making methods and applications," in Berlin: Springer, 1981.

[49] M. S. García-Cascales and M. T. Lamata, "On rank reversal and TOPSIS method," Mathematical and Computer Modelling, vol. 56, pp. 123-132, Sep 2012.

[50] Z. Marković, "Modification Of Topsis Method For Solving Of Multicriteria Tasks," Yugoslav Journal of Operations Research, vol. 20, no. 1, pp. 117-143, 2010.

[51] E. Roszkowska, "Multi-criteria Decision Making Models by Applying the Topsis Method to Crisp and Interval Data," University of Economics in Katowice, vol. 6, pp. 200-230, 2011.

[52] K. B. Tunay and I Akhisar, "Performance Evaluation and Ranking of Turkish Private Banks Using," in Management International Conference, 2015.

[53] L. Haewon, C. Hanbyeol, L. Junyeong, M. Jinyoung and L. Heeseok, "Impact of IT Investment on Firm Performance Based on Technology IT Architecture," Information Technology and Quantitative Management, Procedia Computer Science, vol. 91, pp. 652-661, 2016.

[54] L. Bozga, "Information Technology and the Company Performance in the Sector of Service," Information society and sustainable development, 2015.

[55] A. M. Attiea, M. E. Ibrahim and D. A. Amjad, "Effects of Financial and Non-financial Performance Measures on Customers' Perceptions of Service Quality at Islamic Banks in UAE," International Journal of Economics and Finance, vol. 6, no. 10, 2014.

[56] T. Zhelyuk and C-L. Popa, "Non-financial measurements in banking industries of Sweden, Romania and Ukraine," Master Thesis, The Department of Business Administration, Lund University June 2009. 